\title{
We Have Always Wanted More
}

\section{Susana Tosca}

IT University of Copenhagen, Denmark

doi: 10.7358/ijtl-2015-001-tosc

tosca@itu.dk

\section{ABSTRACT}

This essay proposes the concept of "transmedial desire" to characterize the impulse of audiences to engage with their favourite fictions across different media. I argue that transmedial desire is the essential force that makes fictions become transmedial in the first place and offer some historical examples of three different kinds of desires: experiencing, inhabiting and transforming.

Keywords: transmedial world; desire; fiction; storytelling; audience; experience; transformation.

\section{INTRODUCTION}

When I was eight, I made a Lego Smurf village so that me and my little brother could play with our plastic Smurf figures. It stood for weeks and weeks, occupying a big part of the living room, and we would rush from school everyday to play and make stories in our favourite world. Until my mother got tired of it and put all the pieces in their box, and then inside the cupboard. We were really angry; she had destroyed our world! We really cared about that village, and were extremely invested in the Smurf stories: we read the comic books, watched the cartoons, drew Smurfs all over the place and made up new stories every day which we enacted with our figurines. Without knowing it, we were part of building a transmedial universe; our enthusiasm and love for the characters had made us want to extend their world into different media. And we were by no means the first to do something like this.

This essay will take you in an uneven romp through history in search of traces of transmedial desire. My aim is not (at least not only) to show that transmedial storytelling has always existed, since the act of representing a popular story across different media has probably been there since our prehis- 
toric ancestors painted a tale of a legendary hunt into the walls of a cave. I want to use historical examples to illustrate different desires associated with transmedial representations and the motivations of audiences to engage with them. This is not an empirical paper, even though it is based on previous empirical experience working with transmedial fans (Klastrup and Tosca 2004, 2009, 2011, 2013), it is an essay.

The notion of transmedial desire, which I will define in the next section, is inspired by the work of Peter Brooks and his definition of narrative desire. In Reading for the Plot. Design and Intention in Narrative (1984), Brooks makes a convincing case for applying the psychoanalitic notion of desire to the study of literature. He argues that desire "is always there at the start of a narrative" $(1984,38)$, where the opening paragraphs set a stage that defines what kinds of things the reader will want to know, as the desire to know more is what motivates readers to engage with texts. He looks at the different kinds of "engines" texts can have to afford different kinds of pleasures, all the time insisting in reading as a dynamic and playful operation. His model is built upon Freud's and Lacan's characterization of desire, and the motivation it provides human with, to seek the object of desire (in this case the fulfillment of the story). One of Brooks examples is the Thousand and One Nights, which literally thematizes the desire for a plot, a story that continues into the next night. Shaharazad "cures" the sultan of his sick sadistic death wish "by prolonging it, precisely by narrativizing it. Desire becomes reinvested in tellings of and listenings to stories, it is reconstituted as metonymy - over a thousand and one nights until the Sultan can resume a normal erotic state, marrying Shahrazad" (1984, 60-61). Metonymy is also an illustrative trope to how transmedial fiction works, where experiencing one of the narratives evokes the whole universe. I want to expand Brook's idea of narrative desire, from the single text to the relation to the whole textual universe.

\section{TRAnSmedial Desire}

I define transmedial desire as a pulsion common to enthusiastic audiences that are driven to seek more contact with the fictions they love, turning them into transmedial worlds (Klastrup and Tosca 2004) in the process. Audiences will read more books, watch more movies and revisit the same universe again and again. This pleasure of extending contact with the beloved fiction is similar to that found by Jennifer Hayward in relation to the consumption of serial texts, which, by virtue of their being extended in time, create a world and a desire for completion, of knowing more in Brooks sense (Hayward 1997). 
Hayward is very interested in how serial audiences have different ways of being active, and not all are about producing fan fiction; she stresses the active aspect of "the processes of collaborative interpretation, prediction, metacommentary and creation" (Hayward 1997, 2). This is the same for transmedial audiences, where only a few will take their enthusiasm further and create their own stories within the transmedial universe (such as writers of fan fiction). I deliberately want to also pay attention here to the more "passive" desires of consumption, and not only to those of production. The reason for this, which I will return to at the end of the essay, is that I want to acknowledge and celebrate transmedial desire as an important cultural factor per se, without being distracted by distinctions (and evaluations) of which of its forms is preferable.

Have you ever done it? Daydreamt about being an inhabitant of your favourite fictional world? Debated with Frodo about the best way to get to Mordor while hiking through a forest? Asked yourself what Sherlock Holmes would do to identify the co-worker that systematically steals your soja milk from the common fridge? Played the Star Wars soundtrack on your headphones while you jog, heroically avoiding the imperial forces? You know you have. Maybe you have also created a fiction of your own that inhabits the same universe: a little poem, a short story, a costume party, a computer game... all to make your favourite world come alive. If so, you can be said to suffer from transmedial desire. Suffer because it is, as any desire, a realization about a lack. As Lacan (quoted in Brooks) puts it, desire is born "of the difference or split between need and demand" (Brooks 1984, 55); you want something which you don't have, so you seek it. Unlike other desires though, it is often not difficult to satisfy, especially if your interest is in one of the most popular transmedial worlds such as the examples I introduced above.

Traditionally, transmedia theory has focused on the fictions themselves (trying to figure out the aesthetic characteristics of worlds that have transmedial appeal, Klastrup and Tosca 2004), on the intertextual relations of the different "units" comprising the transmedial world (for example by exploring questions of canon and deviation, like in Leavenworth 2014), or even on the strategic opportunities of transmedial communication (one company launching a story across different media, like in Dena 2011). This emphasis on the fictions and the producers can be traced in the proliferation of expressions such as franchise or media convergence and the many practical guides to transmedial storytelling that have been published in the last five years. When we talk about a franchise, we are considering the strategic planning and making of different fictions within a transmedial universe. But just launching a franchise (even a well made one with a sound business model and solid promotion strategy) is no guarantee that it will become a sucessful transmedial universe. Maybe not enough people will watch your movie, so nobody will play your computer 
game or play with your figurines, and the fora of your fan communities will stay painfully dead as your impact time slot quickly diminishes and disappears. It is not possible to predict what people will fall in love with, and without the enduring enthusiasm of the audience, no transmedial world can exist.

However, not many theorists have talked about the people in the other end of the mediatic and authorial efforts: the transmedial audiences (unless it is to characterize fan production activity, like for example Jenkins 2006). We often ignore that the reason why so many contemporary fictions are parts of transmedial universes is simply because people want them. Many readers/ viewers/users/players are consuming transmedial products without actually never producing any content themselves, which is kind of embarrassing if we think that the only thing that can redeem an audience is their willingness to engage creatively with their source of inspiration/fandom. Instead, many people just seem content to sit back and watch/read/play, maybe going so far as to engage in social media or fan fora discussing plot twists and character deviation problems. From a transmedial desire perspective, they are all contributing to keeping the world alive by the mere act of engaging with it at an interpretive (and sometimes productive) level again and again.

If we adopt an aesthetic perspective, we could say that experiencing the transmedial fiction realizes the work itself, so that the transmedial world becomes into existence every time someone engages in an act of interpretation and aesthetic interaction. This approach is related to the interest that theorists of reception like Jauss, Iser, or Eco have in the active role of recipients, but it goes beyond it, as it imbues the reception act with a creative significance of its own.

This is the philosophical stand behind the definition of transmedial world which Lisbeth Klastrup and I proposed in 2004:

Transmedial worlds are abstract content systems from which a repertoire of fictional stories and characters can be actualized or derived across a variety of media forms. What characterises a transmedial world is that audience and designers share a mental image of the "worldness" (a number of distinguishing features of its universe). (Klastrup and Tosca 2004)

I emphasize "abstract content system" and "mental image" to insist on the fact that we consider the reception/aesthetic experience act as the defining one for the existence of transmedial worlds. In other words, a bunch of interconnected fictions doesn't become a transmedial world until people begin to perceive it as such, and are able to make an abstraction of the world characteristics that are not exclusively tied to any particular plot (in our paper defined as "mythos, topos and ethos", (Klastrup and Tosca 2004). In this essay, I argue that this act of creation is always fuelled by desire. It starts by an effort of comprehension that develops into a wish of experiencing more that can also be 
about inhabiting our favourite worlds, maybe also into a wish of transforming the transmedial world ourselves.

These are the three main aspects of transmedial desire, which I will try to illustrate using some historical examples below. My motivation for using historical examples rather than contemporary ones, is twofold. Firstly, I want to move away from the idea of franchise, and propose examples that are not planned by a corporation but created by the actual audiences; in a way to explore the flip side of spreadability. Secondly, a lot of transmedial theory (our own included) focuses on examples taken from popular culture, particularly genres like fantasy and science fiction. I want to argue that transmedial desire can be detected in other genres and times, including works that we normally identify as belonging to the "high culture" canon.

\subsection{Experiencing more: representation across media}

This desire refers to probably the most straightforward way of media migration, where a character, scene or setting from one story is represented in another medium. A classic example could be Berninis statue representing the myth of Apollo and Daphne, which had been told by Ovid in his Metamorphoses (and which he in turn had reworked inspired by older Greek sources). We enjoy experiencing the same stories in a new way, and also have a wish to display them to the world, to give them flesh in different media.

Emperor Tiberius had his Sperlonga villa decorated with several big statuesque groups retelling the adventures of Odysseus/Ulysses. The statues where strategically placed around a grotto where the emperor liked to dine, with a triclinium built upon an artificial island in the middle of a pool. It must have been quite a marvelous setting, the sculptures illuminated at night, the water and the opening to the sea and the sky. The heroes of old, as it were, invited to dine with the emperor.

But experiencing more is not only just about representation. It can also be about illuminating aspects of the story that were not entirely fleshed out in the original fiction. And the case of Odysseus is again a good example, as we could say that The Odyssey was the first spin-off of literature, with one of the charismatic characters of The Iliad getting his own show.

\subsection{Inbabiting our favourite worlds}

Our passion for certain stories can also compel us to build a world within the real world where we come to briefly inhabit the transmedial universe; that is, 
we go beyond contemplation, and set up a scenography that can be lived in, even if it is a fiction. In our contemporary world it is easy to find examples of this, such as the thematized rides of amusement parks, or the computer games that virtually allow us to have active roles within our favourite fictions. But this desire has also been present in earlier times. I hesitate to name the naumaquias of the romans as the very first example as they typically reenacted historical battles and not fictional ones. But I mention them because they are an extreme example of the lengths humans can go to give flesh to a story, as here by constructing big pools (or flooding an amphiteater), and letting several ships destroy each other, as well as hundreds of men die to entertain the people. It was brutal, expensive and very realistic.

Other world creation enterprises are less dangerous, such as the Neuschwanstein castle constructed for King Ludwig II of Bavaria as a romantic version of a medieval castle, with a lavishly decorated interior so that the king could live out all his wagnerian fantasies. Incidentally, this castle also has an artificial grotto with fake stalactites and a waterfall, that serves as a passage between two areas of the castle. One can only speculate as to what kind of use the king would have given this "room" if he had lived enough to move to the castle for good (he only slept there a few nights before he died), but maybe just passing through the grotto would inspire in one the right aesthetic (romantic) attitude.

Use is important in the habitable transmedial worlds, which have to allow for some reenacment that gives the "user" an experience that is richer than the act of looking. They have to afford some sort of performance that goes beyond aesthetic appreciation.

To illustrate this we can use the example of Queen Marie Antoinette of France's "Hameau de la Reine", a small leisure retreat in one of the parks of Versailles, that is built in the shape of an idyllical rustic village whith a few constructions including among others a farmhous and a barn. The Queen and their friends would spend a lot of time in their private world, fleeing the formalities of the Court, dressed as shepherds and farmers, occassionally milking the cows or taking part in other menial farm duties. The Hameu is not just an attempt to recreate a simple natural life, it is also directly inspired by pastoral literature, an old genre, cultivated since antiquity, that had flourished in France for many years with poets like Honore d'Urfe or Pierre de Ronsard, and painters like Boucher. The Hameau affords direct participation in the transmedial world of pastoral poetry, by enabling a bucolic life of contemplation and simple tasks. 


\subsection{Transforming stories}

The third desire I want to exemplify is a transformational one, where it is not only about recreating the transmedial world in another medium, as in the first desire (where no new elements are incorporated) but also about changing it in various ways. Maybe the reader disagrees with some aspect of the tale, or would like to change the way in which a character behaves, while at the same time respecting the essence of the work. Because I believe that this desire for transformation is always initiated by love of the original subject, even if it ends up rather far from it in some crucial ways, as it happens for example in slash fan fiction.

The simplest way of transforming a story is by adding to it, by extending it, maybe by creating our own version of what happened in a part of the world not covered by the foundational story, or by telling what had happened before or would happen afterwards. I would argue that this is the case of The Aeneid, in which Aeneas, a very minor character of The Iliad, is radically boosted many levels up and becomes the foundational hero of the Roman civilization. It is not, like The Odyssey, a part of the same story; this is a completely different story that covers another part of the world but still wants to keep a strong relation to the main Greek mythos.

Transformations can also be about reframings and reinterpretations that not necessarily result in a full-fledged literary work that contests the first one. Kristina Milnor argues that the popular graffiti found in the walls of Roman Pompeii shows how ordinary people responded and sometimes rewrote aspects of canonical literature of the time (Milnor 2014). And again, as in the other examples, this is a work of love; no reader would bother to write a funny pun about a poem if it hadn't moved her in some way.

But of course the most spectacular transformations are those with a transgressive aspect, either because the philosophy of the original works is twisted into something else, or because the author of the transformation proposes a radical departure/change. A good example of this anarquic spirit is the Quixote of Avellaneda. Miguel de Cervantes had published the first part of Don Quixote in 1605, and had slowly gained quite a lot of success. Nine years later, someone (whose identity we dont know) published a second part of the adventures of the world's most famous knight under the pseudonym of Alonso Fernández de Avellaneda. Cervantes, who was working on his own second part of Don Quixote, was mortified, and used a lot of energy in distancing himself from this person, even though he was more inspired by the content of the apocryphal work that he would like to think. Actually, the content of the Avellaneda Quixote is not anarquic, as it respects the original and continues the adventures in a very believable way (that goes well with the mythos, topos and ethos of the original story). The rebellious spirit is rather due to the fact that 
whomever this fan was, he couldn't wait for the master to write the second part, and so he did it himself ${ }^{1}$.

\section{BY WAY OF CONCLUSION}

I started this essay arguing that transmedial desire was an important cultural factor, as it was the fuel behind a lot of invention of enthusiastic audiences taking their love for a story on to new media, always searching new developments and new scenarios.

If we had to ask why audiences indulge in their transmedial desires, we would have to question why we engage with fictions at all.

The three desires that I have proposed in relation to transmedial worlds are, not surprisingly, well aligned with research about the emotional involvement of readers. Richard Gerrig has proposed to metaphors to understand why people read at all, that of "being transported" and that of "performing" the narrative (Gerrig 1993). It is important to note that performance is not only about reenacting, as in roleplay, which some of my examples above could afford, but also about interpretation and inference (Gerrig 1993, 27). "I believe that many criterial properties of narrative worlds emerge directly from the ordinary and obligatory operation of basic cognitive processes" (239). $\mathrm{He}$ concludes with "Through both active participation and passive acquiescence, our lives are enhanced by richly diverse experiences of narratives (241).

Of course, different media afford different kinds of pleasures, and each medium merits its own analysis. But even scholars who have studied the reasons of why people engage with other media such as videogames (Taylor 2003, Mortensen 2007, Calleja 2011) or cinema (Benshoff and Griffin) report that the desire of inhabiting worlds of fiction is one of the strong attractions of these media. This desire is not named as such in their work, but they talk about the pleasures of experiencing digital environments, or the pleasurable escapism of movies.

I argue that the here proposed transmedial desires are not media specific, but that they ultimately refer to the essence of fictions and our engagement with them as audiences. A logical next step would be to investigate how this approach could enter a productive dialogue with the work of Kendall Walton on mimesis, Frank Zippel on transmedial fictionality or even Yi-Fu Tuan on escapism. I will certainly keep on building.

1 The similarity of this behaviour with fan fiction writing has also been noticed by Spanish scholar José Antonio Millán (http://jamillan.com/quijap.htm). 


\section{REFERENCES}

Benshoff, Harry, and Sean Griffin. 2009. America on Film: Representing Race, Class, Gender, and Sexuality at the Movies. Oxford: Blackwell.

Brooks, Peter. 1984. Reading for the Plot. Design and Intention in Narrative. Cambridge, MA: Harvard University Press.

Calleja, Gordon. 2011. In-Game: From Immersion to Incorporation. Cambridge, MA: MIT Press.

Dena, Christy. 2011. "Do You Have a Big Stick?” if:book Australia, February 7, 2011. January 10, 2015.

Hayward, Jennifer. 1997 Consuming Pleasures. Active Audiences and Serial Fictions from Dickens to Soap Opera. Kentucky: The University Press of Kentucky.

Gerrig, Richard J. 1993. Experiencing Narrative Worlds. On the Psychological Activities of Reading. Boulder: Westview Press.

Jenkins, Henry. 2006. Fans, Bloggers, and Gamers: Exploring Participatory Culture. New York: New York UP.

Klastrup, Lisbeth, and Susana Tosca. 2013 "A Game of Thrones: Transmedial Worlds, Fandom \& Social Gaming”. In Storyworlds Across Media, edited by Marie-Laure Ryan and Jan-Noël Thon, 295-314. Nebraska: University of Nebraska Press.

Klastrup, Lisbeth, and Susana Tosca. 2011. "When Fans Become Players: LOTRO in a Transmedial World Perspective". In Ringbearers. The Lord of the Rings Online as Intertextual Narrative, edited by Tanya Krzywinska, Esther MacCallumStewart and Justin Parsler, 46-69. Manchester: Manchester University Press.

Klastrup, Lisbeth, and Susana Tosca. 2009. "Because it just looks cool!: Fashion as character performance, the case of WOW", Journal of Virtual Worlds Research 1 (3): https://journals.tdl.org/jvwr/index.php/jvwr/article/view/305/427.

Klastrup, Lisbeth, and Susana Tosca. 2004. "Transmedial worlds - rethinking cyberworld design”. In CW2004 Cyberworlds Conference Proceedings. Los Alamitos: IEEE.

Leavenworth, Maria Lindgren. 2013. "Transmedial Narration and Fan Fiction. The Storyworld of The Vampire Diaries". In Storyworlds Across Media, edited by Marie-Laure Ryan and Jan-Noël Thon, 315-331. Nebraska: University of Nebraska Press.

Milnor, Kristina. 2014. Graffiti and the Literary Landscape in Roman Pompeii. Oxford: Oxford University Press.

Mortensen, Torill. 2004. "Flow, Seduction and Mutual Pleasures". In Miguel Sicart and Jonas Heide Smith, Proceedings of Other Players conference. Center for Computer Games Research, IT. University of Copenhagen, Denmark. 6-8 December 2004, http://tilsett.hivolda.no/tm/mortensen_otherPlayers.pdf

Taylor, TL. 2003. "Multiple Pleasures. Women and Online Gaming". Convergence, 9 (1), 21-46. 